ISSN: 2302-8556

E-Jurnal Akuntansi Universitas Udayana

Vol.25.1.Oktober (2018): 300-327

DOI: https://doi.org/10.24843/EJA.2018.v25.i01.p12

\title{
Kendali Budget Ketat pada Pemda Di Provinsi Bali dalam Menghadapi Turbulensi Budget
}

\author{
I Wayan Pradnyantha Wirasedana ${ }^{1}$ \\ Eka Ardhani Sisdyani² \\ I Putu Ery Setiawan ${ }^{3}$
}

${ }_{\text {1 Fakultas Ekonomi dan Bisnis, Universitas Udayana (Unud), Bali, Indonesia }}$
email: ochaw @live.com.au
${ }^{2}$ Fakultas Ekonomi dan Bisnis, Universitas Udayana (Unud), Bali, Indonesia
${ }^{3}$ Fakultas Ekonomi dan Bisnis, Universitas Udayana (Unud), Bali, Indonesia

\begin{abstract}
ABSTRAK
Penelitian ini bertujuan untuk memberikan rekomendasi mengenai tingkat keketatan / fleksibilitas pengendalian budget yang diberlakukan pada pemerintah daerah, khususnya di Provinsi Bali, agar defisit atau surplus budget dapat dihindari dan kinerja budget meningkat. Data diperoleh melalui multiple methods, yaitu survey dengan kuesioner dan observasi dan verifikasi data arsip anggaran dan laporan realisasi anggaran serta data perekonomian makro dari Badan Pusat Statistik Provinsi Bali. Populasi adalah seluruh Pemerintah Kota dan Kabupaten di Provinsi Bali. Sampel ditentukan secara purposive, berdasarkan pemetaan wilayah Tipologi Klassen. Data diuji untuk mengestimasi model pengukuran dan model struktural, dengan Metode Partial Least Square (PLS), dan menguji efek interaksi dengan Regresi Ordinary Least Square (OLS). Hasil penelitian ini dapat digunakan untuk mengantisipasi terjadinya faktor kontinjensi berupa turbulensi budget dalam menjamin efektivitas budgeting, khususnya ketika turbulensi budget ini mempengaruhi hubungan antara pengendalian budget yang ketat dengan terjadinya penyimpangan budget.
\end{abstract}

Kata kunci: kendali budget ketat, turbulensi budget, pemda di Provinsi Bali

\begin{abstract}
This research aimed to provide recommendation on how stringent or flexible budget control held by district government, especially in Bali Province, so that deficits or surpluses can be avoided and budget performance improved. The data were collected from multiple methods including survey using questionnaire, observation, budget archive verification, budget realization report and macro economic data from Badan Pusat Statistik Provinsi Bali. The population was district and town governments in Bali Province and purposive sampling was used, based on Klassen Typology. The data was tested to estimate measurement and structural models using Partial Least Square (PLS) method and interaction effect test using Ordinary Least Square (OLS) method. The result of this research can be used to anticipate contingency factor such as budget turbulence in guaranteeing budget efficiency, especially when budget turbulence affect the relationship of stringent budget control and budget deviation.
\end{abstract}

Keywords: stringent budget control, budget turbulence, district and town governments 
I Wayan Pradnyantha Wirasedana, Eka Ardhani S, dan I Putu Ery Setiawan. Kendali...

\section{PENDAHULUAN}

Sebagaimana halnya dengan organisasi sektor privat, organisasi sektor publik (OSP), seperti perusahaan milik negara/daerah, pemerintahan daerah, dan yayasan non profit motives, juga seringkali dihadapkan pada persoalan dalam budgeting. Budgeting merupakan suatu tahapan pengelolaan dana masyarakat yang sangat penting, sebelum kegiatan dan program dapat dieksekusi. Budget juga penting sebagai benchmark terhadap capaian kinerja sehingga efektifitas program dapat diukur.

Setiap organisasi menghadapi kendala yang sama dalam hal ketersediaan sumberdaya. Sumberdaya yang tersedia pasti terbatas. Oleh karena itu alokasinya untuk meningkatkan kesejahteraan masyarakat harus mendapat perhatian yang memadai. Proses alokasi tersebut difasilitasi dalam budgeting. Proses tersebut, khususnya pada OSP, sering dipengaruhi oleh kepentingan-kepentingan politis yang berbenturan. Tarik-menarik kepentingan merupakan hal biasa. Hal ini lah yang menjadikan budgeting pada OSP lebih complicated.

Masalah pada budgeting di sektor publik, khususnya organisasi pemerintahan, berlanjut pada tahapan eksekusinya yang berkaitan erat dengan pengendaliannya. Eksekusi budget yang ideal adalah yang berimbang, sehingga pemerintah daerah sedapat mungkin menghindari surplus budget, apalagi defisit. Surplus budget di tingkat pemerintah daerah memang bukanlah menunjukkan suatu prestasi. Hal ini justru menimbulkan pertanyaan tentang ketidakmampuannya menyusun budget dan ketidakdisiplinan dalam mengeksekusi budget (Johansson dan Siverbo, 2014) dalam bentuk program kerja 
atau kegiatan. Defisit budget sangat sulit dimungkinkan pada pemerintah daerah, karena proses revisi budget untuk menambah alokasi sumberdaya memerlukan proses yang panjang dan rigid. Oleh karena itu, budget deviasi menjadi hal yang sangat krusial untuk dikendalikan pada pemerintah daerah. Kegagalan mengendalikan budget akan berdampak pada pencapaian kinerja tahun berjalan dan penyusunan budget tahun yang akan datang.

Masalah lainnya yang dihadapi pemerintah daerah adalah ketersediaan sumberdaya yang sering berfluktuasi dari tahun ke tahun. Fluktuasi tersebut kemungkinan disebabkan oleh perkembangan lingkungan ekonomi mikro dan makro, termasuk perubahan kebijakan pemerintah, seperti: kebijakan fiskal, moneter, prediksi pendapatan dari jasa layanan publik, dan lain-lain. Keadaan ini lah yang disebut sebagai turbulensi budget (Boyne \& Meier, 2009).

Pemerintah daerah yang telah menerapkan otonomi daerah memiliki wewenang untuk mengatur keuangan daerahnya masing-masing, termasuk dalam penyusunan, eksekusi, dan pengendalian budget. Walaupun demikian, turbulensi budget tetap menjadi ancaman yang harus dikelola dengan baik. Salah satu cara yang dapat dilakukan adalah dengan menerapkan kendali ketat terhadap budget yang telah ditetapkan. Penelitian mengenai budget control system telah banyak dilakukan, namun masih didominasi oleh organisasi di sektor privat, dan sedikit yang menghubungkan pengendalian budget dengan kinerja budget (AnessiPessina et al., 2012).

Penelitian ini berfokus pada peranan kendali budget ketat (KBK) dalam mengurangi deviasi budget pada pemerintahan daerah yang menghadapi 
I Wayan Pradnyantha Wirasedana, Eka Ardhani S, dan I Putu Ery Setiawan. Kendali...

turbulensi lingkungan ekonomi dalam bentuk budget yang berubah-ubah, yaitu perubahan sasaran, spending limit, prioritas, maupun level kinerja. Hal ini sesuai dengan kondisi budgeting process berbasis kinerja yang diterapkan pada pemerintahan daerah di Indonesia. Jadi turbulensi budget merupakan faktor kontinjensi yang mempengaruhi peranan KBK dalam mengendalikan deviasi budget. OSP (dalam hal ini pemerintah daerah) merupakan setting yang tepat untuk menguji tipe interaksi teori kontinjensi, karena memiliki karakteristik khusus, yaitu persaingan yang relatif kurang, adanya benturan kepentingan, dan melibatkan proses-proses yang bersifat politis dan demokratis. Penelitian ini juga dalam rangka merespon perlunya lebih banyak riset tentang efek positif kendali budget, bukan hanya berfokus pada diysfunctional effect dari kendali budget, seperti perilaku dari para aktor yang terlibat dalam pengelolaan budget.

Berdasarkan perkembangan indikator ekonomi Provinsi Bali, sebagaimana disajikan pada Tabel 1, nampak bahwa pendapatan asli daerah (PAD) secara absolut mengalami peningkatan, namun laju pertumbuhan PDRB dan Gini Ratio justru berfluktuasi. Hal ini menunjukkan kondisi turbulensi dalam perekonomian makro Provinsi Bali yang akan mempengaruhi ketersediaan sumberdaya yang dapat dialokasikan dalam budget pemerintah daerah di Provinsi Bali.

Lebih lanjut, Gini Ratio mengukur ketimpangan ekonomi secara agregat antar wilayah yang terjadi di Provinsi Bali. Faktor-faktor penyebab terjadinya ketimpangan ekonomi antar wilayah tersebut merupakan faktor-faktor penentu ketersediaan sumberdaya yang dapat digunakan untuk menbiayai program dan kegiatan pemerintah daerah. Selain itu, laju pertumbuhan ekonomi juga 
ISSN: 2302-8556

E-Jurnal Akuntansi Universitas Udayana

Vol.25.1.Oktober (2018): 300-327

mempengaruhi ketersediaan sumberdaya anggaran. Analisis pola pertumbuhan ekonomi dapat dilakukan dengan menggunakan Tipologi Klassen (Mardiana, 2012).

Tabel 1.

Perkembangan Indikator Ekonomi Provinsi Bali Tahun 2011 -2015

\begin{tabular}{cccc}
\hline Tahun & PAD (Rupiah) & $\begin{array}{c}\text { Laju Pertumbuhan } \\
\text { PDRB ADHK 2010 }(\boldsymbol{\%})\end{array}$ & Gini Ratio \\
\hline 2011 & 1.723 .807 .096 .000 & 6,49 & 0,410 \\
2012 & 2.042 .091 .096 .000 & 6,96 & 0,430 \\
2013 & 2.529 .976 .147 .000 & 6,69 & 0,403 \\
2014 & 2.920 .416 .697 .075 & 6,73 & 0,415 \\
2015 & 3.041 .266 .607 .000 & 6,04 & 0,377 \\
\hline \multicolumn{2}{l}{ Sumber: Bali dalam Angka Tahun 2012 sampai dengan 2016 }
\end{tabular}

Penelitian ini mengelompokkan daerah kabupaten dan kota di Bali, sesuai dengan kategori dalam Tipologi Klassen yang diusulkan oleh Utami Dewi et al., 2011), yaitu: daerah yang maju dan tumbuh cepat yaitu Kabupaten Badung, daerah berkembang cepat tetapi tidak maju, yaitu Kota Denpasar, Kabupaten Gianyar dan Kabupaten Buleleng, daerah maju tapi tertekan, yaitu Kabupaten Klungkung dan daerah tertinggal yaitu Kabupaten Tabanan, Jembrana, Bangli dan Karangasem.

Penggunaan Tipologi Klassen ini dimaksudkan untuk mengetahui peranan kendali budget ketat (KBK) dalam mengurangi deviasi budget pada pemerintahan daerah dengan pola pertumbuhan ekonomi yang berbeda di Provinsi Bali.

Penelitian ini penting dilakukan karena beberapa motivasi berikut: (1) Turbulensi (ketidakstabilan) akan ketersediaan sumberdaya untuk menyusun budget yang dihadapi oleh Pemda di Provinsi Bali dapat mengancam efektivitas pelaksanaan program dan kegiatan peningkatan kesejahteraan masyarakat. Oleh karena itu, penting untuk mengantisipasi terjadinya faktor kontinjensi ini dalam 
I Wayan Pradnyantha Wirasedana, Eka Ardhani S, dan I Putu Ery Setiawan. Kendali...

menjamin efektivitas budgeting, khususnya ketika turbulensi budget ini mempengaruhi hubungan antara pengendalian budget yang ketat dengan terjadinya penyimpangan budget. (2) Kebijakan pengendalian budget secara ketat sangat diperlukan dalam upaya menjamin tercapainya kinerja yang mengedepankan perwujudan konsep value for money: ekonomis, efisiensi, dan efektif. Deviasi budget, baik surplus maupun defisit sedapat mungkin dihindari, karena keduanya bersifat problematik bagi Pemda yang bersangkutan.

Dari sudut pandang demokratis dan normatif under-spending yang mengakibatkan terjadinya surplus adalah tidak sah, karena secara politis alokasi sumberdaya seharusnya digunakan untuk meningkatkan kesejahteraan masyarakat. Under-spending dapat menimbulkan isu atau reaksi, terutama dari media massa, lembaga swadaya masyarakat (LSM), bahkan publik, bahwa pemda tidak dapat memanfaatkan dana publik yang tersedia untuk kepentingan publik (Wldavsky 1975).

Over-spending, yang menimbulkan defisit budget juga tidak dikehendaki, atau bahkan tidak dimungkinkan, karena ketidaktersediaan sumberdaya untuk menambah belanja pemerintah melebihi budget. Bahkan, over-spending terhadap budget di beberapa negara disebut sebagai tindakan ilegal dan dapat dikenai sanksi hukum (Johansson dan Siverbo, 2014).

Masalah yang sering dihadapi pemda dalam menyusun dan merealisasikan budget adalah menentukan sumberdaya yang tersedia untuk digunakan dalam penyusunan budget, yaitu sisi rencana anggaran penerimaannya. Anggaran penerimaan pemda sangat tergantung pada ketersediaan sumber-sumber 
penerimaan asli daerah, kebijakan pemerintah pusat, kebijakan pemerintah daerah, dan kondisi makro ekonomi lainnya. Jadi jumlah sumberdaya yang tersedia untuk dianggarkan senantiasa berfluktuasi dari tahun ke tahun. Inilah yang disebutkan oleh Boyne dan Meier (2009) sebagai kondisi turbulensi budget.

Turbulensi budget tidak hanya dapat dilihat dari ketersediaan sumberdaya yang berfluktuasi. Performance-based budgeting yang diadopsi oleh pemerintah daerah menutup peluang penyusunan budget berbasis incrementalism. Sasaran, spending limit, prioritas, maupun level kinerja harus ditetapkan berbasis tujuan kinerja tahun yang bersangkutan yang bisa jadi berbeda dengan tahun sebelumnya. Bahkan dimungkinkan untuk menerapkan zero-based budgeting, mengingat analisis kebutuhan dan prioritas kegiatan ditentukan untuk setiap tahun anggaran. Keadaan ini juga berdampak pada meningkatnya turbulensi budget yang dihadapi oleh pemda.

Turbulensi budget menjadi faktor kontinjensi dalam hubungan antara kontrol budget ketat (KBK) dengan deviasi budget. Teori Kontinjensi telah mendominasi riset-riset di bidang perilaku organisasi, perencanaan, pengukuran kinerja dan manajemen stratejik. Teori ini memiliki preposisi bahwa outcome organisasi merupakan dampak dari dua atau lebih faktor secara bersama-sama (Van de Ven, A H dan Drazin, R., 1984). Alasan untuk mengasumsikan hubungan kontinjensi dan bukannya hubungan universal antara KBK dengan deviasi budget adalah bahwa situasi yang ada mungkin membutuhkan kendali budget yang lebih ketat atau lebih longgar dalam proses pengendalian budget. Kunci untuk memahami efek kontinjensi ini adalah kemungkinan perbedaan yang dibutuhkan 
I Wayan Pradnyantha Wirasedana, Eka Ardhani S, dan I Putu Ery Setiawan. Kendali...

untuk memberikan arahan dalam organisasi (Simons 1987). Pada organisasi sektor publik yang menghadapi turbulensi budgetyang signifikan, memungkinkan terjadinya problem inkongruensi tujuan antara manajer pusat dengan manajer departemen meningkat atau semakin penting. Dalam situasi turbulensi budget rendah atau tidak ada, dan di mana proses budgeting-nya bersifat incrementalism, kebutuhan dan hasil dari KBK kemungkinan berbeda. Turbulensi budget yang rendah berarti bahwa organisasi hanya secara marginal memulai dari anggaran tahun sebelumnya (Boyne et al. 2000). Penelitian-penelitian sebelumnya tentang penganggaran di sektor publik menunjukkan bahwa perubahan incremental meningkatkan rasa kepastian sementara turbulensi menciptakan ketidakpastian yang harus ditangani (Wildavsky 1975). Argumen ini sejalan dengan penelitianpenelitian sebelumnya yang telah menyelidiki hubungan serupa untuk organisasi sektor swasta (Khandwalla, 1978, Ezzamel 1990, Gosh et. al. 2012); dan Johansson dan Siverbo (2014) yang meneliti di sektor publik.

Deviasi budget merupakan dimensi kinerja yang sangat penting bagi organisasi sektor publik (OSP), khususnya pemerintahan daerah. Hal ini disebabkan oleh adanya tekanan politik dan institusional yang mengharuskan pemerintah daerah untuk tidak melakukan pembelanjaan berlebih atau kurang, sehingga realisasi budget berimbang dengan rencana budget tersebut. Deviasi budget merupakan isu penting dalam pengendalian anggaran yang dilakukan secara ketat. Oleh karena itu, budget harus disusun dengan cermat berdasarkan sasaran/target kinerja yang dapat diukur dengan jelas sesuai dengan rencana strategis dan rencana operasional pemda yang bersangkutan. 
ISSN: 2302-8556

E-Jurnal Akuntansi Universitas Udayana

Vol.25.1.Oktober (2018): 300-327

Dalam organisasi sektor publik, budget merupakan hasil negosiasi politik dan penentuan skala prioritas, sehingga menunjukkan keinginan dari politisi yang berkuasa dan secara tidak langsung keinginan dari orang-orang tersebut. Tekanan dan dorongan untuk meniadakan deviasi budget menjadikan kendali budget penting. Tujuan pengendalian budget adalah mengarahkan anggota organisasi untuk bertindak yang terbaik demi kepentingan organisasi (Mechant dan Van der Stede, 2012).

Ada tekanan koersif bagi OSP untuk tidak melewati budget limit (cost),dan tidak banyak atau bahkan tidak ada insentif jika terjadi surplus. Bahkan akan muncul dugaan bahwa organisasi yang bersangktan mengalami too much funding. Surplus penting pada level nasional, bukan pada level individual OSP.Selanjutnya, Hasanah, Wahyudi, dan Nugroho (2016) menyatakan bahwa defisit budget yang dibiayai dari pinjaman, baik intern maupun ekstern juga ternyata tidak berdampak pada konsumsi sektor privat dan neraca perdagangan. Jadi salah satu dimensi kinerja budget yang penting dalam OSP adalah menghindari (mengendalikan) deviasi budget. Prosesnya meliputisettingtarget budget, mengevaluasi varians budget; dan memberikan reward pada kinerja yang baik.

Kendali budget ketat adalah gabungan antara intensitas dan lingkup kontrol manajemen untuk meningkatkan ketercapaian budget (Merchant \& Van der Stede, 2012). Pembentukan kendali budget ketat dikonseptualisasikan sebagai keadaan dimana manajemen pusat memberikan penekanan pada manajemen lokal untuk mencapai pemenuhan anggaran, dan tidak menerima revisi anggaran yang 
I Wayan Pradnyantha Wirasedana, Eka Ardhani S, dan I Putu Ery Setiawan. Kendali...

dilakukan pada tahun berjalan. Secara rinci, Van der Stede (2001) menyebutkan bahwa konstruk dari KBK dikonsepsualisasikan ada jika manajemen pusat: Menekankan pada pencapaian budget; Tidak menerima revisi budget; Memiliki ketertarikan pada detil budget; Tidak mentoleransi deviasi dari target interim budget; dan Secara intensif melakukan komunikasi terkait masalah budget.

Namun demikian, kendali budget ketat juga berarti peningkatan biaya sistem pengendalian (Hartman 2000). Biaya tersebut meliputi biaya langsung dan tidak langsung. Biaya langsung berkaitan dengan biaya manajemen dan sistem, sedangkan biaya tidak langsung antara lain terdiri atas: terjadinya slack budget, tekanan yang berkaitan dengan pekerjaan, dan sikap negatif dari pelaksana budget. Sehingga KBK dibenarkan hanya ketika mendatangkan manfaat yang melebihi pengorbanan yang terjadi akibat efek dysfunctional yang ditimbulkannya.Jika diduga bahwa manfaat KBK tidak mampu melebihi cost-nya, maka pemerintah seharusnya mempertimbangkan penerapan budget yang lebih fleksibel, namun dengan tetap mengontrol dana publik dengan membangun rerangka hubungan antara keuangan pusat dan lembaga yang mengotorisasi belanja publik dalam bentuk regulasi yang tegas (Di Francesco \& Alford, 2016).

Jadi, ketika KBK dihubungkan dengan deviasi budget, cukup beralasan untuk berasumsi bahwa KBK hanya berdampak positif pada deviasi budget ketika terdapat turbulensi budget yang signifikan.Dengan kata lain, dampak KBK pada budget deviation tergantung (kontinjen) pada besar-kecilnya budget turbulence. Oleh karena itu, hipotesis penelitian ini adalah bahwa pada keadaan dimana 
turbulensi budget bersifat signifikan, penerapan kendali budget ketat akan mengurangi deviasi budget.

Pembahasan tentang Tipologi Klassen dalam penelitian ini penting karena berkaitan dengan penentuan lokasi penelitian. Lokasi penelitian dipilih sesuai dengan pengelompokan kabupaten dan kota di Provinsi Bali berdasarkan pertumbuhan ekonominya. Pertumbuhan ekonomi daerah sangat menentukan ketersediaan sumberdaya anggaran daerah sehingga berkontribusi pada tingkat turbulensi budget yang dihadapi oleh pemerintah daerah masing-masing.

Ketidakseimbangan petumbuhan ekonomi antar kabupaten dan kota dalam suatu wilayah tertentu dapat menyebabkan terjadinya ketimpangan ekonomi antar wilayah. Hal ini lah yang menyebabkan tingkat kesejahteraan masyarakat menjadi berbeda. Menurut Sjafrizal (2008), ketimpangan ekonomi dapat disebabkan oleh beberapa hal, diantaranya adalah perbedaan potensi sumberdaya alam; kondisi demografis yang berbeda; perbedaan dalam kelancaran arus barang dan jasa; perbedaan dalam pemusatan kegiatan ekonomi; dan perbedaan besarnya alokasi dana pembangunan. Hal-hal ini lah yang pada akhirnya turut menentukan ketersediaan sumberdaya yang dapat digunakan dalam budget daerah.

Klassen Typology adalah alat analisis ekonomi regional yang bertujuan untuk memetakan pola dan struktur pertumbuhan ekonomi pada daerah-daerah tertentu dalam suatu wilayah.Dua indikator utama pada Tipologi Klassen terdiri dari economic growthdan pendapatan per kapita. Berdasarkan analisis ini karateristik pola dan struktur pertumbuhan ekonomi dibedakan menjadi empat kategori, yang terdiri atas daerah yang maju dan tumbuh cepat, daerah maju tapi 
I Wayan Pradnyantha Wirasedana, Eka Ardhani S, dan I Putu Ery Setiawan. Kendali...

tertekan, daerah yang masih dapat berkembang pesat, dan daerah relatif tertinggal (Kuncoro dan Aswandi, 2002).

Penelitian ini mengelompokkan daerah kabupaten dan kota di Bali, sesuai dengan kategori dalam Tipologi Klassen yang diusulkan oleh Utami Dewi et al., 2011), yaitu: daerah yang maju dan tumbuh cepat yaitu Kabupaten Badung daerah berkembang cepat tetapi tidak maju, yaitu Kota Denpasar, Kabupaten Gianyar dan Kabupaten Buleleng, daerah maju tapi tertekan, yaitu Kabupaten Klungkung dan daerah tertinggal yaitu Kabupaten Tabanan, Jembrana, Bangli dan Karangasem.

Berdasarkan pengelompokan ini, akan diambil sampel masing-masing satu pemda untuk mewakili masing-masing kelompok berdasarkan tipologi Klassen, yaitu pemda yang mengelola anggaran dengan jumlah rupiah absolut terbesar. Dengan demikian dapat diperoleh perbandingan tingkat keketatan kendali anggaran untuk daerah-daerah yang berbeda pertumbuhan ekonominya.

\section{METODE PENELITIAN}

Penelitian ini merupakan kelanjutan dari penelitian sebelumnya tentang aspek keperilakuan dalam proses penyusun budget. Dalam penelitian ini budget yang telah disusun menjadi objek penelitian, yaitu pada realisasinya, khususnya pada aspek keketatan pengendalian budget untuk menghindari terjadinya deviasi budget. Hubungan tersebut diduga bersifat kontinjen pada kondisi tingkat turbulensi yang dihadapi oleh pemda yang bersangkutan dalam menyusun dan merealisasikan budget. Hasil penelitian ini akan memberikan implikasi pada 
tingkat keketatan pengendalian budget dan penerapan kebijakan budget ketat pada pemerintahan daerah di Provinsi Bali.

Selanjutnya, masalah yang terkait dengan anggaran pemda adalah penilaian kinerja budget yang menerapkan kebijakan kendali budget ketat, yaitu kinerja yang meliputi pencapaian budget (analisis varians) dan kinerja jangka panjang terkait pencapaian outcome. Penelitian selanjutnya akan melakukan analisis varians pada pencapaian budget dan menentukan penyebabnya serta memberikan rekomendasi untuk perbaikan berkelanjutan.

Penelitian ini mengambil lokasi berdasarkan kategori wilayah Provinsi Bali dengan menggunakan hasil dari Analisis Tipologi Klassen. Untuk penelitian selanjutnya akan dilakukan pengujian terhadap perbedaan tingkat keketatan pengendalian budget dan perbandingan kinerja budget di antara wilayah yang termasuk ke dalam empat kategori tersebut.

Penelitian ini merupakan penelitian yang menggunakan analisis kuantitatif. Data dikumpulkan dari beberapa sumber. Sumber yang pertama adalah sumber data primer dari responden penelitian dengan menggunakan kuesioner untuk mendapatkan data tentang tingkat keketatan pengendalian budget pada Pemkot dan Pemkab di Provinsi Bali. Responden adalah seluruh kepala dinas yang berada pada Pemkot/Pemkab yang dijadikan sampel penelitian. Sumber data yang lain adalah data sekunder yang diperoleh dari Badan Pusat Statistik Provinsi Bali dan data budget serta laporan keuangan (khususnya laporan realisasi anggaran) yang diperoleh dari Pemkot/Pemkab yang bersangkutan. 
Data yang telah terkumpul dianalisis reliabilitas dan validitasnya, untuk kemudian diuji untuk mengestimasi model pengukuran dan model struktural, dengan Metode Partial Least Square (PLS), dan menguji efek interaksi dengan Regresi Ordinary Least Square (OLS).

\section{RISET SEBELUMNYA}

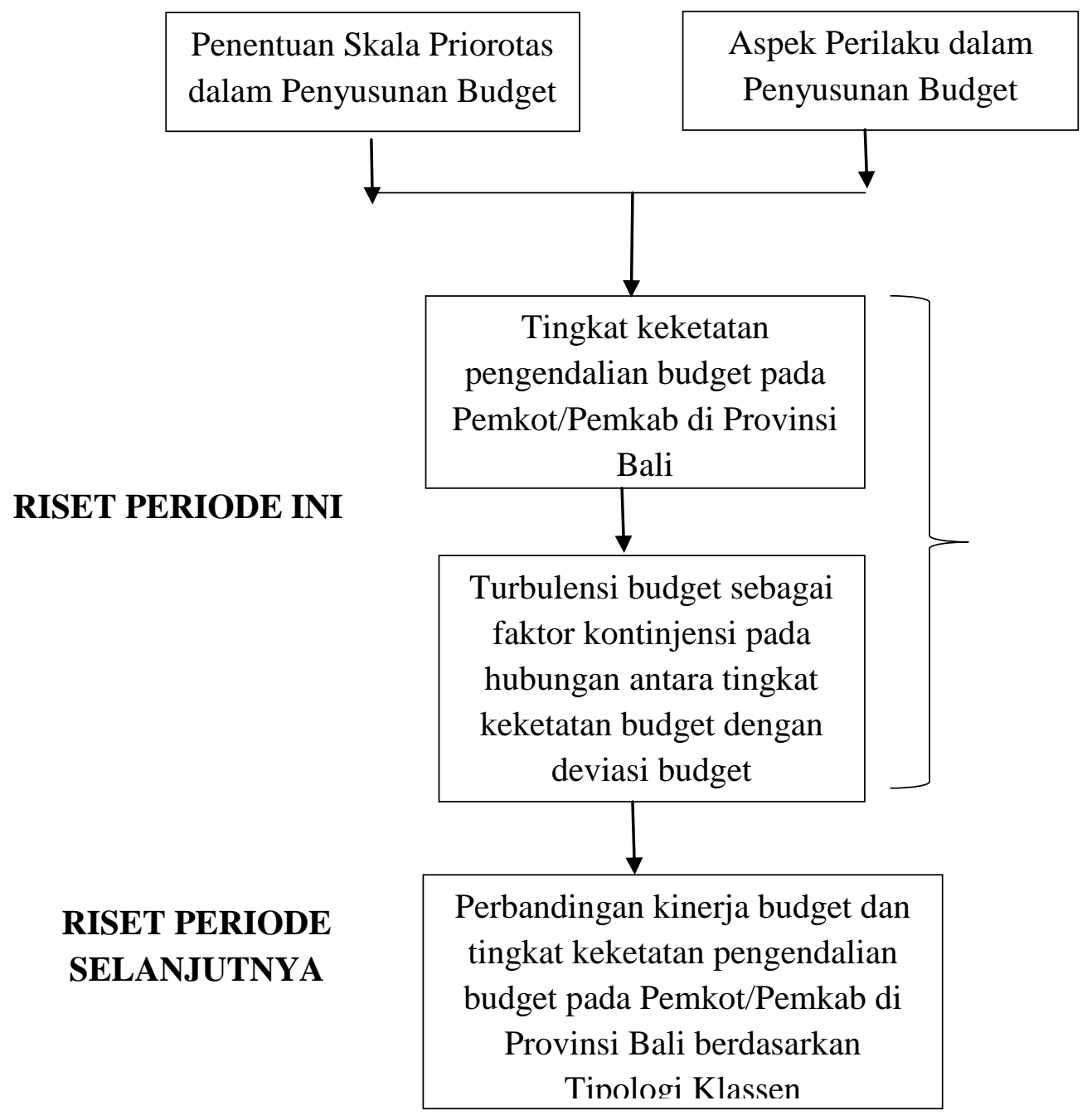

Gambar 1.

Road Map Penelitian 
Ruang lingkup penelitian ini adalah efek kontinjensi turbulensi budget pada hubungan antara kendali budget ketat $(\mathrm{KBK})$ dan deviasi budget. Walaupun demikian, terdapat potensi hubungan antara turbulensi budget dan deviasi budget, deviasi budget periode lalu dengan deviasi budget periode berjalan, dan deviasi budget periode lalu dengan KBK.

Variabel dalam penelitian ini adalah: (1) Variabel independen: Kendali budget ketat (KBK) dioperasionalisasikan dan diukur dengan konstruk yang digunakan oleh Johansson dan Siverbo (2014): (a) Menekankan pada pencapaian budget (emphasis), (b) Memiliki minat mendetail pada item lini budget (detail), (c) Tidak mudah mentoleransi deviasi budget (deviate) dan (d) Secara intensif mengkomunikasikan hal-hal terkait budget (intensity). (2) Variabel dependen: Deviasi budget, dioperasionalisasikan sebagai perbandingan antara budget dan realisasi (Johansson dan Siverbo, 2014). Deviasi budget $=($ budgeted cost $2016-$ actual cost 2016)/actual cost 2016. Deviasi budget tahun lalu $=($ budgeted cost 2015 - actual cost 2015)/actual cost 2015. Jika deviasi budget bernilai positif berarti realisasi lebih kecil dari budget, dan sebaliknya. (3) Variabel kontinjensi: Turbulensi budget, dioperasionalisasikan sebagai perbandingan antara sumberdaya yang tersedia untuk dibudgetkan pada tahun $\mathrm{n}$ dengan realisasi budget pada tahun n-1 (Johansson dan Siverbo, 2014). Turbulensi budget = (budgeted revenue 2016 - actual cost 2015)/actual cost 2015. Budgeted revenue merupakan jumlah sumberdaya yang tersedia untuk digunakan dalam budget.

Penelitian ini menggunakan metode pengumpulan data berupa survey dan observasi dokumen. Metode survey digunakan untuk mengukur keketatan kendali 
I Wayan Pradnyantha Wirasedana, Eka Ardhani S, dan I Putu Ery Setiawan. Kendali...

budget dengan menggunakan kuesioner yang diadopsi dari Johansson dan Siverbo (2014), yang menderivasi konstruk KBK yang dikembangkan oleh Van der Stede (2001).Kegiatan pengumpulan data dilakukan oleh peneliti dengan bantuan 2 orang mahasiswa Program Studi Akuntansi.

Observasi dokumen dilakukan terhadap budget dan laporan realisasinya, dan selanjutnya diverifikasi dengan data yang diperoleh dari survey. Penggunaan multiple methods dalam pengumpulan data dapat meminimalisir atau menghindari terjadinya common method bias (Podsakoff, P.M., MacKenzie, S.B., Podsakoff, N.P., 2003).

Populasi melingkupi seluruh pemda di Provinsi Bali, dengan pengelompokan berdasarkan Tipologi Klassen, yaitu: daerah yang maju dan tumbuh cepat yaitu Kabupaten Badung, daerah berkembang cepat tetapi tidak maju, yaitu Kota Denpasar, Kabupaten Gianyar dan Kabupaten Buleleng, daerah maju tapi tertekan, yaitu Kabupaten Klungkung dan daerah tertinggal yaitu Kabupaten Tabanan, Jembrana, Bangli dan Karangasem.

Pemda yang dijadikan sampel secara purposiveadalah masing-masing satu pemda dari setiap kelompok. Jika dalam satu kelompok terdapat lebih dari satu pemda, maka akan dipilih pemda yang mengelola budget terbesar secara absolut, karena diasumsikan memiliki tanggung jawab pencapaian budget yang relatif lebih berat. Tabel 2 menyajikan jumlah agregat Anggaran Pendapatan dan Belanja Daerah untuk seluruh kabupaten/kota di Provinsi Bali pada tahun anggaran 2016. 
Tabel 2.

Jumlah Agregat APBD Kabupaten/Kota di Provinsi Bali Tahun 2016

\begin{tabular}{lccc}
\hline Kabupaten/Kota & $\begin{array}{c}\text { Pendapatan }(\mathbf{R p} \\
\text { triliun) }\end{array}$ & $\begin{array}{c}\text { Belanja } \\
\text { (Rp triliun) }\end{array}$ & $\begin{array}{c}\text { Surplus (Defisit) (Rp } \\
\text { triliun) }\end{array}$ \\
\hline Badung & 4,07 & 4,54 & $(0,47)$ \\
Gianyar & 1,62 & 1,92 & $(0,29)$ \\
Tabanan & 1,49 & 1,51 & $(0,02)$ \\
Klungkung & 1,06 & 1,13 & $(0,07)$ \\
Jembrana & 1,05 & 1,09 & $(0,04)$ \\
Karangasem & 1,45 & 1,57 & $(0,12)$ \\
Bangli & 1,03 & 1,14 & $(0,11)$ \\
Buleleng & 1,90 & 1,97 & $(0,07)$ \\
Denpasar & 2,05 & 1,26 & 0,79 \\
\hline
\end{tabular}

Sumber: Ringkasan APBD Kabupaten dan Kota di Provinsi Bali, 2016

Berdasarkan Tabel 2 maka yang akan dijadikan sampel karena mengelola budget terbesar dalam masing-masing kategori adalah sebagai berikut.

Daerah yang maju dan tumbuh cepat: Kabupaten Badung.

Daerah berkembang cepat tetapi tidak maju: Kota Denpasar

Daerah maju tapi tertekan: Kabupaten Klungkung.

Daerah tertinggal: Kabupaten Tabanan.

Dari masing-masing pemda yang terpilih sebagai sampel, selanjutnya akan diambil seluruh SKPD Dinasyang merupakan cost centeruntuk dipilih sebagai responden penelitian. SKPD Dinascost center dipilih karena merupakan pusat pertanggungjawaban yang berkaitan langsung dengan pelayanan kepada publik.

Teknik analisis data yang digunakan adalah analisis kuantitatif dengan urutan sebagai berikut.

Menguji reliabilitas dan validitas model pengukuran KBK (Hair et al., 2010): 
I Wayan Pradnyantha Wirasedana, Eka Ardhani S, dan I Putu Ery Setiawan. Kendali...

Reliabilitas diukur dengan composite reliability dan average variance extracted (AVE) untuk empat konstruk dari KBK. Kriterianya adalah jika composite reliability-nya lebih besar dari pada 0,7 dan AVE lebih besar dari 0,5 berarti reliabel.

Validitas diukur dengan menggunakan nilai loading factor dari variabel laten KBK, yaitu Detail, Deviate, Intensity, dan Emphasis. Kriterianya adalah valid jika loading factor bernilai lebih besar dari pada 0,6.

Menguji model:

Metode Partial Least Square (PLS): untuk mengestimasi model pengukuran dan model struktural (Hair Jr, Hult, Ringle, \& Sarstedt, 2016). SmartPLS softwaredigunakan untuk membantu pengolahan data.

Uji Goodness of Fit (GoF)

Kriteria: jika GoF>0,36 maka berarti model memiliki daya prediktif/eksplanatori yang baik.

Menguji hipotesis dan model struktural termasuk pengaruh interaksinya, dengan menggunakan Regresi Ordinary Least Square (OLS) (Beaton, Dunlop, \& Abdi, 2016), dengan menggunakan pendekatan dua tahap:

Tahap I: estimasi model yang meliputi pengaruh langsung dan utama dari variabel independen (KBK) pada variabel dependen (Deviasi Budget).

Tahap II: estimasi model yang sama dengan Tahap I, namun dengan menambahkan interaksi antara turbulensi budget dengan KBK. 
ISSN: 2302-8556

E-Jurnal Akuntansi Universitas Udayana

Vol.25.1.Oktober (2018): 300-327

\section{HASIL DAN PEMBAHASAN}

Penelitian ini mengumpulkan data melalui kombinasi antara survey dan data arsip. Survey dilakukan untuk mengumpulkan data keketatan budget, sedangkan data arsip digunakan untuk mengumpulkan data angka budget dan angka realisasi budget pada Kantor Dinas yang merupakan cost centre di Provinsi Bali. Berdasarkan sampel yang ditargetkan yang diambil secara purposive, pada empat Pemda, yaitu Kabupaten Badung, Tabanan, Klungkung, dan Kota Denpasar, sampai dengan saat ini telah terkumpul 55 kuesioner dari target sebanyak 62 . Rincian data berdasarkan wilayah dapat dilihat pada Tabel 3.

Tabel 3.

Distribusi responden berdasarkan Wilayah Pemda/Pemkot di Bali

\begin{tabular}{lccccc}
\hline \multirow{2}{*}{ Kabupaten/Kota } & \multicolumn{2}{c}{ Jumlah Direncanakan } & \multicolumn{2}{c}{ Jumlah Direalisasikan } & \multirow{2}{*}{ Capaian (\%) } \\
\cline { 2 - 5 } & Absolut & $\boldsymbol{\%}$ & Absolut & \% & \\
\hline Badung & 18 & 29 & 18 & 33 & 100 \\
Tabanan & 15 & 24 & 15 & 27 & 100 \\
Klungkung & 11 & 18 & 11 & 20 & 100 \\
Denpasar & 18 & 29 & 11 & 20 & 61 \\
\hline Jumlah & 62 & 100 & 55 & 100 & 89 \\
\hline
\end{tabular}

Sumber: Data diolah, 2017

Tabel 3 memetakan hasil pengumpulan data lapangan yang menunjukkan bahwa secara keseluruhan tingkat pengembalian kuesioner adalah 89 persen. Meskipun response rate sebesar 89 persen dikatakan telah memenuhi persyaratan untuk pengolahan data dalam penelitian yang mengumpulkan data dengan menggunakan metode survey dengan kuesioner, namun data yang dikumpulkan belum tersebar secara merata, khususnya data di Kota Denpasar; sedangkan untuk tiga kabupaten yang lain, seluruh kuesioner kembali dan dapat digunakan. Hal ini menunjukkan komitmen yang kuat dalam membantu pengembangan ilmu 
I Wayan Pradnyantha Wirasedana, Eka Ardhani S, dan I Putu Ery Setiawan. Kendali...

pengetahuan, khususnya di bidang penganggaran sektor publik yang juga terkait dengan praktik akuntansi di lembaga-lembaga pemerintahan, termasuk Pemda.Yang harus diberikan apresiasi adalah responden di Kabupaten Klungkung, karena meskipun seluruh dinas tengah disibukkan dengan terlibat aktif pada penanganan masalah pengungsi dari Kabupaten Karangasem akibat status 'awas' Gunung Agung yang telah berlaku sejak bulan Agustus 2017 (kondisi force majeure), namun tetap menyempatkan diri untuk berpartisipasi dalam penelitian ini. Profil responden berdasarkan latar belakang demografinya disajikan pada Tabel 4 .

Tabel 4.

Profil Responden berdasarkan Demografi

\begin{tabular}{llcc}
\hline & Keterangan & Jumlah & Persentase (\%) \\
\hline Jenis Kelamin & Laki-laki & 32 & 58 \\
& Perempuan & 23 & 42 \\
& Jumlah & 55 & 100 \\
Pendidikan & SMU & 1 & 2 \\
& S1 & 34 & 63 \\
& S2 dan Profesi & 19 & 35 \\
& Jumlah & 55 & 100 \\
& Ka Dinas & 11 & 20 \\
& Kasubag Keuangan & 27 & 49 \\
Lama Jabatan & Staf/Bendahara/Sekrataris & 17 & 31 \\
& Jumlah & 55 & 100 \\
& Lebih dari 1 Tahun & 43 & 78 \\
& Kurang dari 1 Tahun & 12 & 22 \\
& Jumlah & 55 & 100 \\
\cline { 2 - 3 } & & & \\
& Lum & & \\
& & 5 &
\end{tabular}

Sumber: Data diolah, 2017

Tabel 4 menunjukkan bahwa sebagian besar responden adalah laki-laki, berpendidikan terakhir setara sarjana strata 1, menjabat sebagai Kepala Sub Bagian Keuangan pada Dinas masing-masing, dan telah menjabat selama lebih dari satu tahun. Dengan latar belakang demografi tersebut, dapat dikatakan bahwa responden telah memiliki karakteristik yang memadai untuk menjadi responden 
penelitian ini. Satu orang yang berpendidikan SMU merupakan staf bagian perencanaan yang telah berpengalaman pada bagian tersebut selama lima tahun, sehingga telah memiliki pengalaman yang memadai untuk dapat mengisi kuesioner dengan baik.

Hasil statistik deskriptif dari variabel-variabel yang dioperasikan dalam penelitian ini dapat dilihat pada Tabel 5.

Tabel 5.

Statistik Deskriptif Variabel Penelitian Statistics

\begin{tabular}{|c|c|c|c|c|c|c|c|}
\hline & & Emp & Det & Dev & Int & $\begin{array}{c}\text { Dev- } \\
\text { Budget }\end{array}$ & $\begin{array}{c}\text { Turbulens } \\
\mathbf{i}\end{array}$ \\
\hline \multirow[t]{2}{*}{$\mathrm{N}$} & Valid & 32 & 32 & 32 & 32 & 32 & 32 \\
\hline & Missing & 0 & 0 & 0 & 0 & 0 & 0 \\
\hline Mean & & 3.9641 & 4.0738 & 4.0313 & 3.9638 & .2286 & .1203 \\
\hline Std. Error of Mean & & .13451 & .12838 & .13127 & .13145 & .14118 & .07261 \\
\hline Median & & 4.0000 & 4.0000 & 4.00000 & 4.0000 & .0620 & .1130 \\
\hline Mode & & 4.00 & 4.00 & 4.00 & 4.00 & .04 & $-.65 \mathrm{a}$ \\
\hline Std. Deviation & & .76089 & .72625 & .74257 & .74358 & .79863 & .41074 \\
\hline Variance & & .579 & .527 & .551 & .553 & .638 & .169 \\
\hline Range & & 2.57 & 2.33 & 2.25 & 2.33 & 4.57 & 1.82 \\
\hline Minimum & & 2.43 & 2.67 & 2.75 & 2.67 & .02 & -.65 \\
\hline Maximum & & 5.00 & 5.00 & 5.00 & 5.00 & 4.59 & 1.16 \\
\hline Sum & & 126.85 & 130.36 & 129.00 & 126.84 & 7.32 & 3.85 \\
\hline
\end{tabular}

Sumber: Data diolah, 2017

Tabel 5 menunjukkan statistik deskriptif variabel-variabel penelitian. Variabel dependen dalam penelitian ini adalah deviasi budget (Dev_Budget), sedangkan variabel independen adalah kendali budget ketat (KBK) yang terdiri dari empat konstruk, yaitu emphasis (Emp), detail (Det), deviate (Dev), dan intensity (Int). Hubungan antara variabel independen dengan variabel dependen dimoderasi oleh variabel kontinjensi, yaitu Turbulensi Budget (Turbulensi). 
I Wayan Pradnyantha Wirasedana, Eka Ardhani S, dan I Putu Ery Setiawan. Kendali...

Reliabilitas diukur dengan composite reliability dan average variance extracted (AVE) untuk empat konstruk dari KBK. Kriterianya adalah jika composite reliability-nya lebih besar dari pada 0,7 dan AVE lebih besar dari 0,5 berarti reliabel. Hasil pengujian terhadap reliabilitas konstruk menunjukkan bahwa composite reliability dari keempat konstrukKBK adalah sebesar 0,885 , dengan AVE sebesar 0,662, yang berarti reliabel. Selain itu pengujian terhadap konstruk KBK ini dilakukan pula dengan pengukuran berdasarkan Cronbach's Alpha, yaitu sebesar 0,832. Sehingga dapat dikatakan bahwa seluruh konstruk yang membentuk variable $\mathrm{KBK}$, yaitu emphasis (Emp), detail (Det), deviate (Dev), dan intensity (Int) adalah reliabel.

Validitas diukur dengan menggunakan nilai loading factor dari variabel laten KBK, yaitu Detail, Deviate, Intensity, dan Emphasis. Kriterianya adalah valid jika loading factor bernilai lebih besar dari pada 0,6.Berdasarkan hasil uji discriminant validity, keempat variabel laten dari KBK adalah valid, dengan loading factor berturut-turut adalah Detail 0,823; Deviate 0,895; Emphasis 0,634; dan Intensity 0,877 .

Model penelitian ini terdiri atas model pengaruh langsung (tanpa moderasi), yang disebut sebagai Model I, dan model dengan moderasi, yang disebut dengan Model II. Gambar 2 menyajikan Model I . 


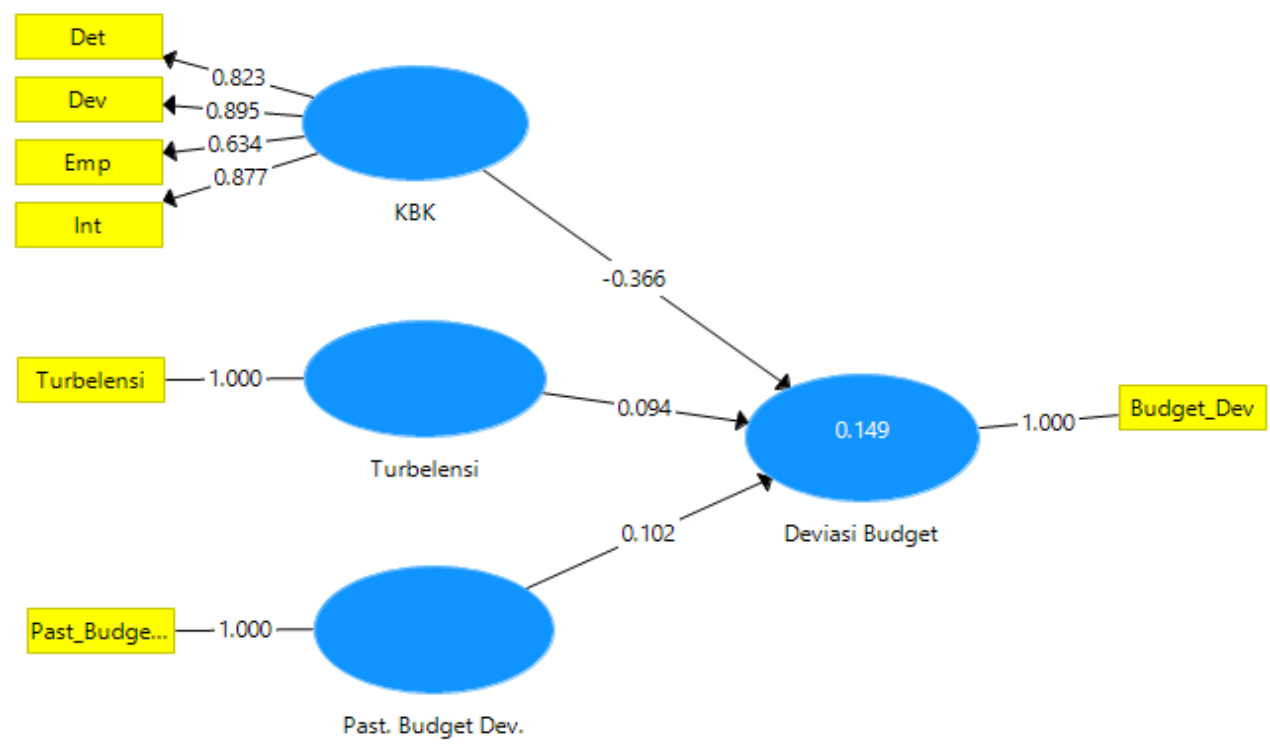

Gambar 2.

\section{Model I Pengaruh Langsung antara KBK dengan Deviasi Budget}

Gambar 2 menunjukkan loading factor dari setiap konstruk KBK dan hubungan langsung dari variabel independen $(\mathrm{KBK})$ dengan variabel dependen (Deviasi budget). Hubungan lainnya, yaitu turbulensi dan past budget deviation dengan deviasi budget juga digambarkan namun fokusnya pada pengaruh langsung KBK pada deviasi budget.

Pengujian hipotesis dilakukan dengan dua tahap, yaitu tahap I menguji pengaruh langsung dan utama dari variabel independen (KBK) pada variabel dependen (Deviasi Budget).

Selanjutnya pengujian tahap II interaksi antara turbulensi budget dengan KBK dan pengaruhnya pada Deviasi Budget. 
I Wayan Pradnyantha Wirasedana, Eka Ardhani S, dan I Putu Ery Setiawan. Kendali...

Hasil pengujian tahap I disajikan pada Gambar 3

\section{Latent Variables}

\begin{tabular}{|l|r|r|r|r|}
\hline \multirow{2}{*}{ Latent Variable Scores } & Latent Variable Correlations & & Latent Variable Covariances \\
\hline & Deviasi Budget & KBK & Past. Budget D... & Turbelensi \\
\hline Deviasi Budget & 1.000 & & \\
KBK & -0.362 & 1.000 & 1.000 \\
\hline Past. Budget Dev. & 0.032 & 0.178 & -0.059 & 1.000 \\
\hline Turbelensi & 0.144 & -0.153 & \\
\hline
\end{tabular}

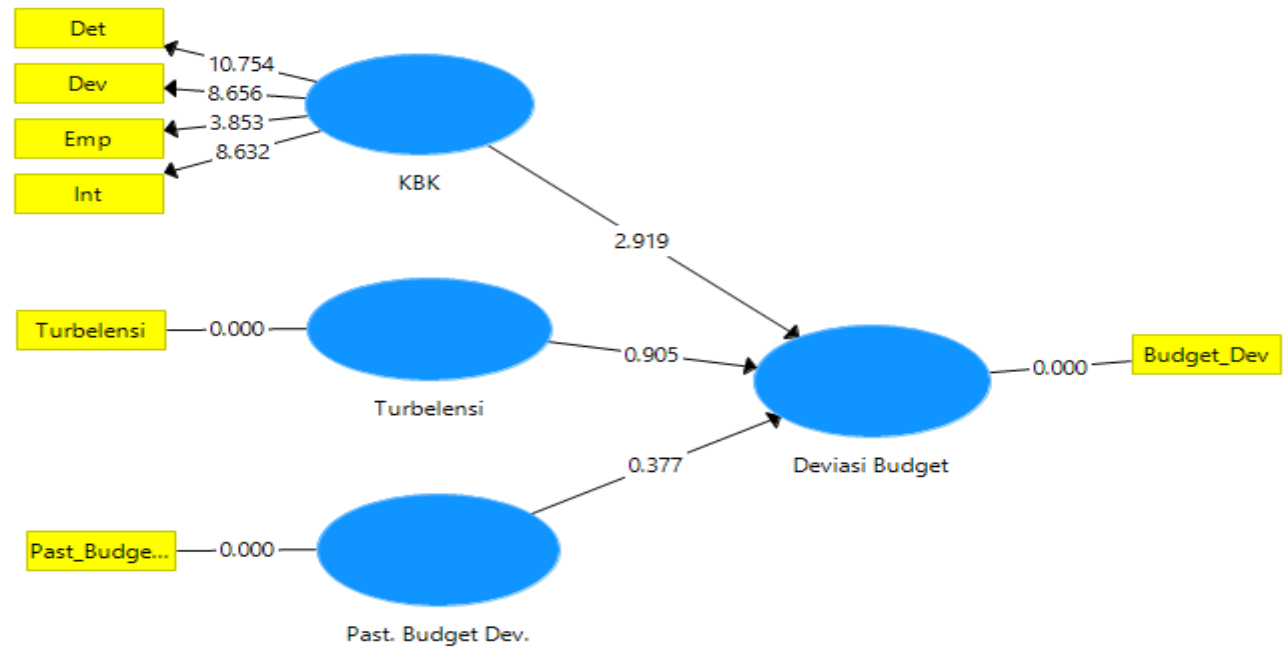

Gambar 3.

Hasil Uji Hipotesis Tahap I

Berdasarkan Gambar 3 nampak bahwa variabel latent KBK berkorelasi negatif dengan deviasi budget. Untuk melihat tingkat signifikansinya, maka dibandingkan antara t-tabel dan t-hitung. T-hitung untuk semua konstruk KBK adalah lebih besar daripada 1,96 (t-tabel). Demikian pula t-hitung pengaruh langsung antara KBK dengan Deviasi Budget, yaitu sebesar 2,919; sehingga dapat disimpulkan bahwa KBK berpengaruh negatif dan signifikan pada deviasi budget. 
ISSN: 2302-8556

E-Jurnal Akuntansi Universitas Udayana

Vol.25.1.Oktober (2018): 300-327

Hasil pengujian tahap II, yaitu dengan menginteraksikan KBK dan turbulensi disajikan pada Gambar 4.

\section{Total Effects}

\begin{tabular}{|c|c|c|c|c|c|c|c|}
\hline \multirow[t]{2}{*}{ Mean, STDEV, T-Values,... } & 国 Confidence Intervals & \multicolumn{3}{|c|}{ Confidence Intervals B... } & Samples & Export to clipboard: & 聂 Copy to clipboard \\
\hline & \multicolumn{2}{|c|}{ Original Sampl... } & Sample Mean (... & & indard Devia... & T Statistics $(\mid 0 \ldots$ & P Values \\
\hline \multicolumn{2}{|l|}{ KBK $\rightarrow$ Deviasi Budget } & -0.336 & -0.300 & & 0.119 & 2.832 & 0.005 \\
\hline \multicolumn{2}{|c|}{ KBKxTurbelensi $\rightarrow>$ Deviasi Budget } & -0.293 & -0.262 & & 0.146 & 2.008 & 0.045 \\
\hline \multicolumn{2}{|c|}{ Past. Budget Dev, -> Deviasi Budget } & 0.073 & 0.282 & & 0.283 & 0.257 & 0.798 \\
\hline \multicolumn{2}{|l|}{ Turbelensi -> Deviasi Budget } & $-0,008$ & 0.007 & & 0.097 & 0.084 & 0.933 \\
\hline
\end{tabular}

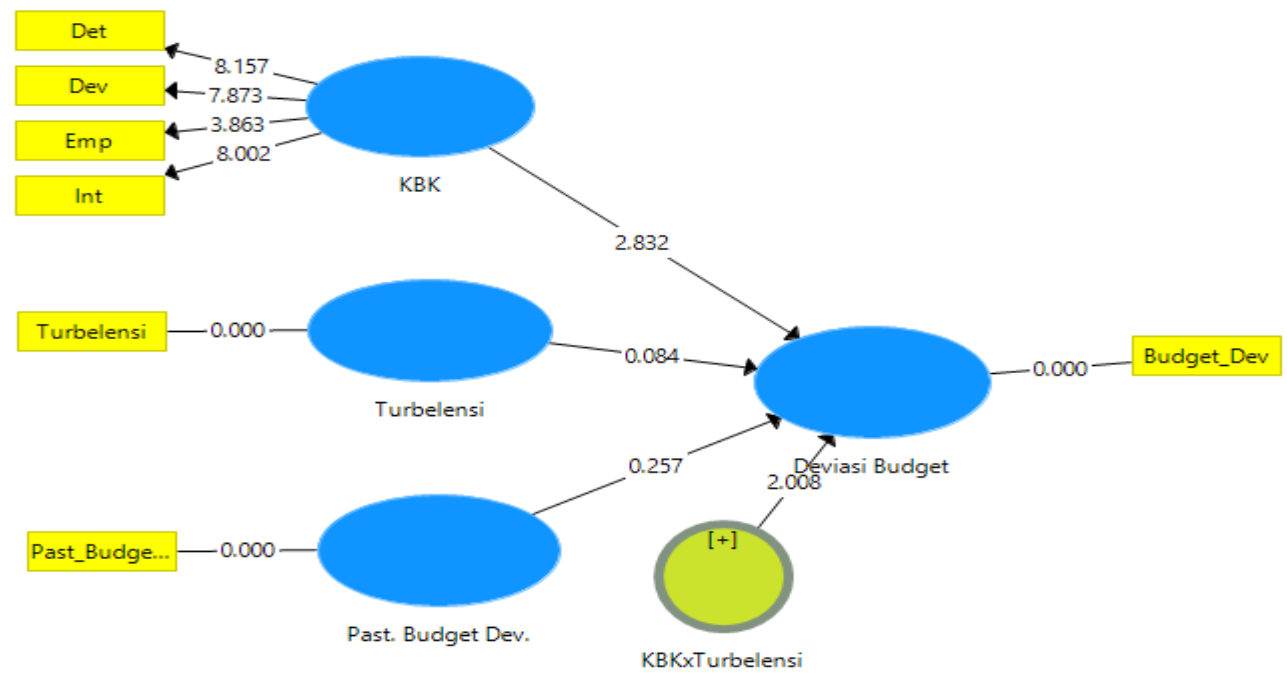

Gambar 4.

Hasil Uji Hipotesis Tahap II (dengan moderasi)

Gambar 4 menunjukkan bahwa jika diuji terpisah, turbulensi tidak berpengaruh pada deviasi budget, tetapi ketika diinteraksikan dengan KBK pengaruhnya menjadi signifikan. Hal ini menunjukkan bahwa untuk Pemda di Provinsi Bali, turbulensi budget yang dihadapi tidak sampai mengakibatkan terjadinya deviasi budget. Tingkat keketatan pengendalian budget-lah yang merupakan faktor utama terjadinya deviasi budget. 
I Wayan Pradnyantha Wirasedana, Eka Ardhani S, dan I Putu Ery Setiawan. Kendali...

\section{SIMPULAN}

Berdasarkan hasil analisis data, dapat disimpulkan bahwa kendali budget ketat berpengaruh negatif pada deviasi budget di beberapa Pemda di Provinsi Bali, sesuai dengan pengelompokan Tipologi Klassen, yaitu Kabupaten Badung, Tabanan, Klungkung, dan Kota Denpasar. Jadi semakin ketat pengendalian budget semakin kecil deviasi budget. Jika diuji terpisah, turbulensi tidak berpengaruh pada deviasi budget, tetapi ketika diinteraksikan dengan KBK pengaruhnya menjadi signifikan. Hal ini menunjukkan bahwa untuk Pemda di Provinsi Bali, turbulensi budget yang dihadapi tidak sampai mengakibatkan terjadinya deviasi budget. Tingkat keketatan pengendalian budget-lah yang merupakan faktor utama terjadinya deviasi budget.

Kebijakan pengendalian budget secara ketat sangat diperlukan dalam upaya menjamin tercapainya kinerja yang mengedepankan perwujudan konsep value for money: ekonomis, efisiensi, dan efektif. Deviasi budget, baik surplus maupun defisit sedapat mungkin dihindari, karena keduanya bersifat problematik bagi Pemda yang bersangkutan.

\section{REFERENSI}

Anessi-Pessina, E., Barbera, C., Rota, S., Sicilia, M., Steccolini, I. (2012). Public sector budgeting in European accounting and public management journals: a review. In: Presented at 7th International Conference on Accounting, Auditing \& Management in Public Sector Reforms, Rome.

Badan Pusat Statistik. Bali dalam Angka Tahun 2012 sampai dengan 2016. Denpasar 
Beaton, D., Dunlop, J., \& Abdi, H. (2016). Partial least squares correspondence analysis: A framework to simultaneously analyze behavioral and genetic data. Psychological methods, 21(4), 621.

Boyne, G., Ashworth, R., Powell, M. (2000). Testing the limits of incrementalism: an empirical analysis of expenditure decisions by English local authorities, 1981-1996. Public Administration. 78, 51-73.

Boyne, G., Meier, K.J. (2009). Environmental turbulence, organizational stability, and public service performance. Administration \& Society. 40, 799-824.

Di Francesco, M., \& Alford, J. (2016). Balancing budget control and flexibility: the central finance agency as 'responsive regulator'. Public Management Review, 1-18.

Ezzamel, M. (1990). The impact of environmental uncertainty, managerial autonomy and size on budget characteristics. Management Accounting Research. 1, 181-197.

Gosh, D., Willinger, G.L., 2012. Management control systems, environmental uncertainty and organizational slack: empirical evidence. Adv. Manage. Acc. 21, 87-117.

Johansson, T., Siverbo, S. (2014). The appropriateness of tight budget control in public sector organizations facing budget turbulence. Management Accounting Research. http://dx.doi.org/10.1016/j.mar.2014.04.001

Hair, J.F., Black, W.C., Babin, B.J., Anderson, R.E., Tatham, R.L. (2010). Multivariate Data Analysis, 7th ed. Pearson Prentice Hall, Upper Saddle River, NJ.

Hair Jr, J. F., Hult, G. T. M., Ringle, C., \& Sarstedt, M. (2016). A primer on partial least squares structural equation modeling (PLS-SEM). Sage Publications.

Hartmann, F.G.H. (2000). The appropriateness of RAPM: toward the further development of theory. Accounting Organization \& Society. 25, 451-482.

Hasanah, E. U., Wahyudi, D., \& Nugroho, J. P. (2016). The government budget deficit and the real sector in indonesia. Proceeding ICOBAME. 
I Wayan Pradnyantha Wirasedana, Eka Ardhani S, dan I Putu Ery Setiawan. Kendali...

Khandwalla, P. (1977). Design of Organizations. Harcourt Brace Jovanovich, New York.

Kuncoro, Mudrajad dan Hairul Aswandi. (2002). Evaluasi Penetapan Kawasan Andalan: Studi Empiris di Kalimantan Selatan 1993-1999, Jurnal Ekonomi dan Bisnis Indonesia Vol.17, No. 1, 27 - 45

Mardiana, Soulma Arum. (2012). Kondisi Ketimpangan Ekonomi Antar Kabupaten/Kota dan Implikasinya terhadap Kebijakan Pembangunan di Provinsi Jawa Timur.http://repository.ipb.ac.id/handle/123456789/58164

Merchant, K.A., Van der Stede, W.A. (2012). Management Control Systems: Performance Measurement, Evaluation, and Incentives. Pearson Education, Harlow, UK.

Podsakoff, P.M., MacKenzie, S.B., Podsakoff, N.P. (2003). Common Method Biases in Behavioral Research: A Critical Review of the Literature and Recommended Remedies. Journal of Applied Psychology Vol. 88, No. 5, 879-903 0021-9010/03/\$12.00 DOI: 10.1037/002-9010.88.5.879

Simons, R. (1987). Accounting control systems and business strategy: an empirical analysis. Accounting Organization \& Society. 12, 357-374.

Sjafrizal. (2008). Ekonomi Regional: Teori dan Aplikasi. Padang: Baduose Media.

Utami Dewi, Ida Ayu Indah et al. (2013). Analisis ketimpangan pembangunan antara kabupaten/kota di Provinsi Bali. Disertasi. FEB Universitas Udayana

Van de Ven, A.H., Drazin, R. (1984). The Concept of Fit in Contingency Theory. Minnesota Univ Minneapolis Strategic Management Research Center. ADA152603.

Wildavsky, A., 1975. Budgeting: A Comparative Theory of Budget Processes. Little, Brown and Co., Boston. 